\title{
Environmental Assessment at the Bakhuis Bauxite Concession: Small- Sized Mammal Diversity and Abundance in the Lowland Humid Forests of Suriname
}

\author{
Burton K. Lim* \\ Department of Natural History, Royal Ontario Museum, 100 Queen's Park, Toronto, Ontario M5S 2C6, Canada
}

\begin{abstract}
A small mammal survey was conducted in the Bakhuis Mountains of western Suriname in South America as part of a larger environmental and social impact assessment for a proposed bauxite mining concession. The objectives were to establish a baseline study of species diversity and relative abundance for comparison of seasonality, areas, and habitats to facilitate the identification and monitoring of potential impacts of mining to the environment. There were 83 species of small mammals documented comprising 68 species of bats, 8 species of rats and mice, and 7 species of opossums. The most abundant bat was the Seba's short-tailed bat, Carollia perspicillata Linnaeus, which was recorded at all six study sites. The most abundant non-volant small mammal was the Guianan spiny rat, Proechimys guyannensis E. Geoffroy. Noteworthy discoveries during the survey include the documentation of four species of bats new to the fauna of Suriname (Cyttarops alecto Thomas, smoky sheath-tailed bat; Saccopteryx gymnura Thomas; least two-lined sac-winged bat; Diaemus youngi Jentink; bird-feeding vampire bat; and Lasiurus egregius Peters, greater red bat). There were no obvious differences between the dry and wet season samplings that were attributable directly to climatic conditions. In terms of spatial variation, the relative abundance of bats among the five study sites within the concession area was similar to each other, but significantly different from a sixth study site at a nearby ecotourism operation, which had large numbers of three species (C. perspicillata; Molossus molossus, common free-tailed bat; and Sturnira lilium, little yellowshouldered bat) that are better adapted to human modified surroundings. This suggests that the recent mining explorations in Bakhuis have had a relatively minor impact on bats and that the otherwise pristine forests within the concession can tolerate low levels of disturbance in proportionally small areas over a short duration. For specific habitats, the xeric forest on plateaus had a reduced subset of species of small mammals that were found in the mesic forest of the surrounding lowland regions, which was acting as a species reservoir for upland areas. Small mammals, in particular bats as primary seed dispersers and flower pollinators, are important components of the ecosystem for the successful reforestation of natural habitats, and factors related to community structure are good indicators of the health of the environment.
\end{abstract}

\section{INTRODUCTION}

Environmental assessments are necessary for the identification and mitigation of potential impacts from sustainable development projects, such as mining of natural resources. In unexplored areas, an initial biodiversity survey establishes a baseline reference source for long term monitoring programs, which will eventually result in a comprehensive inventory of species [1]. Unlike inventory or ecological studies designed to replicate multiple samplings in several areas and habitats over many years, environmental assessments are short-term surveys conducted over several months that require extrapolation from baseline data. Representative sites are sampled from which data on species diversity and relative abundance are analyzed for predictions of impacts on the environment and for gauging the success of rehabilitation programs.

As part of an Environmental and Social Impact Assessment (ESIA) for a proposed bauxite (aluminum ore) mine in the Bakhuis Mountains of Suriname, a small mammal study was conducted. Mammals less than $1 \mathrm{~kg}$ in body mass

*Address correspondence to this author at the Department of Natural History, Royal Ontario Museum, 100 Queen's Park, Toronto, Ontario M5S 2C6, Canada; Tel: 1-416-586-5771; Fax: 1-416-586-7921; E-mail: burtonl@rom.on.ca comprise almost $80 \%$ of the mammalian species diversity in tropical South America. In particular, bats represent about half of the mammal species in the Neotropics [2]. They also are important components of the forest ecosystem because many are fruit, nectar, and insect feeders that are responsible for maintaining natural forest succession through seed dispersal and flower pollination, and as controllers of insect populations. These attributes make bats an important group to study for environmental assessments and monitoring programs. Although the non-volant small mammals (rats, mice, squirrels, and opossums) comprise a smaller proportion of the diversity, their territorial ranges are usually more restricted than that for bats. This biological aspect is a good complement to the more vagile bats and important for evaluating the possible effects of mining disturbances on species diversity and relative abundance.

Unfortunately, there have been no previous comprehensive studies and no published papers summarizing the small mammal diversity in the Bakhuis region, however, there are incidental reports [3] and miscellaneous collections from western Suriname made by the Carnegie Museum of Natural History in Pittsburgh [4-7]. The best documented site for mammals in Suriname is Brownsberg Nature Park, which has recorded 58 bats, 16 rats and mice, 2 squirrels, and 10 opossums [8]. The most abundant species of bat was Seba's short-tailed fruit bat (Carollia perspicillata Linneaus). In 


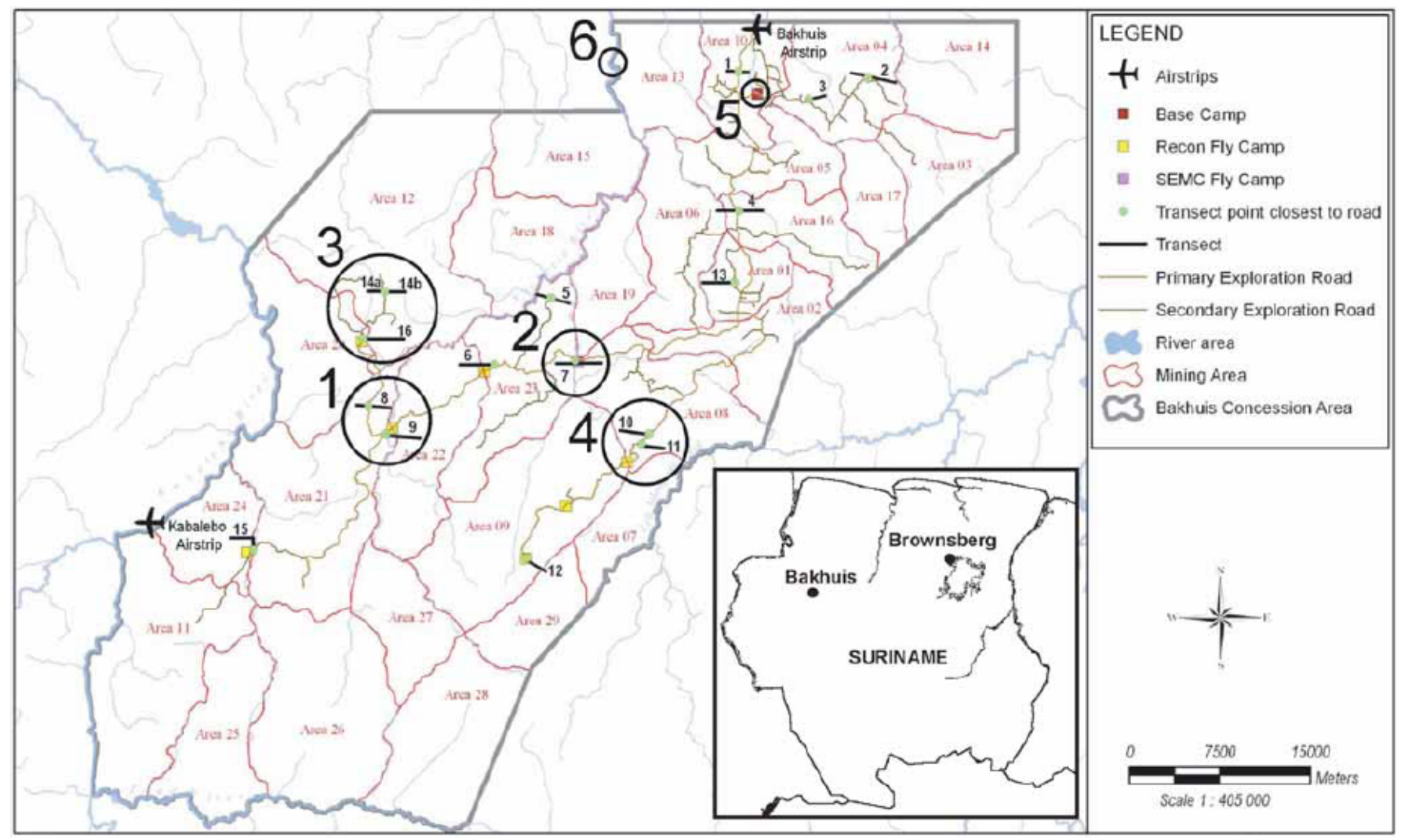

Fig. (1). Map of the Bakhuis bauxite mining concession with locations of fly camps, transects, and roads. The areas surveyed for the small mammal study during the dry season are encompassed by circles numbered as follows: 1) Area 22 Recon Fly Camp; and 2) SEMC Fly Camp. The wet season sampling areas are encompassed by circles numbered as follows: 3) Area 20 Recon Fly Camp; 4) Area 8 Camp; 5) Base Camp; and 6) Blanche Marie Vallen. The inset map indicates the location of Bakhuis and Brownsberg, which is the most comprehensively surveyed site for mammals in Suriname.

addition, the two most abundant species of non-volant small mammals were the Guianan spiny rat (Proechimys guyannensis E. Geoffroyi) and the delicate slender opossum (Marmosops parvidens Tate). The objectives of my study reported herein are to gather baseline data on small mammal diversity and abundance for comparing areas, habitats, and seasonality as part of an environmental assessment for a proposed mining operation at Bakhuis, Suriname.

\section{MATERIALS AND METHODS}

\section{Study Site}

The Bakhuis Bauxite Exploration Concession is approximately $2,800 \mathrm{~km}^{2}$ in area and situated within the Bakhuis Mountains of western Suriname (Fig. 1). The topography is undulating terrain with plateaus reaching $500 \mathrm{~m}$ in elevation with many steep slopes and ridges covered by primary forest. As with the majority of Suriname, most of the land cover in the concession and the surrounding region is classified as lowland humid forest [9], although there is a high degree of heterogeneity in riverine areas and the presence of upland dry forest on plateaus. The only noticeable disturbances to the current environment are the mining exploration roads and camps that were recently constructed over the past two years. However, there also have been several intermittent smaller scale mining operations since the 1970's.
Two field surveys comprised the small mammal baseline study within the Bakhuis concession. The dry season sampling was centered on two exploration camp sites in areas with pre-cut transects in the vicinity (Fig. 1): (1) Area 22 Recon Fly Camp (N 4 $28^{\circ} 41$ " W $57^{\circ} 2^{\prime} 30$ ”, $170 \mathrm{~m}$ ) including Transect 9 was surveyed for 12 nights from 28 October to 8 November 2005. The camp was situated in a large clearing in riverine forest adjacent to the Nickerie River and within tall mesic forest. Transect 8 ( $\mathrm{N}^{\circ} 28^{\prime}$ '33"' W $57^{\circ}$ 3' 26", $290 \mathrm{~m}$ ) was located approximately $3 \mathrm{~km} \mathrm{NW}$ of camp in adjacent Area 21 and surveyed for bats on two evenings. The general habitat was dwarf meso-xeric forest on hard caps with gnarled trees (mountain savanna forest). (2) SEMC Fly Camp (N 4\%32'46" W 57 3'46”, $175 \mathrm{~m}$ ) in Area 23 including Transect 7 was surveyed for five nights on 10 and 14-17 November 2005. The camp was situated in a large clearing in secondary vegetation beside an unnamed tributary of the Nickerie River. The general habitat was tall mesic forest on relatively flat terrain but there were patches of low canopy meso-xeric forest with dense tangles in liana forest and riverine forest.

The wet season sampling was centered on four camp sites: (3) Area 20 Recon Fly Camp (N 432'46" W 57³'46”, $175 \mathrm{~m}$ ) including Transect 13 was surveyed for 13 nights from 11-23 January 2006. The camp was situated in a large clearing beside a small tributary of the Nickerie River and within a valley surrounded by tall mesic forest on steep 
slopes. Approximately $5 \mathrm{~km} \mathrm{NE}$ of camp was Transect 14 ( $4^{\circ} 34$ '53' W $57^{\circ} 2$ ' 48', $293 \mathrm{~m}$ ) in adjacent Area 12. It was located in dwarf or low meso-xeric forest on ironstone and bauxite hard cap and surveyed for five nights. (4) A new camp in Area 8 ( $\mathrm{N} \mathrm{4} 4^{\circ} 27^{\prime} 33^{\prime \prime} \mathrm{W} 56^{\circ} 51^{\prime} 30^{\prime \prime}, 260 \mathrm{~m}$ ) was constructed approximately $2 \mathrm{~km} \mathrm{NE}$ of the old Area 7 Recon Fly Camp, which was constructed two years earlier. The new camp was situated in a valley near a small creek tributary of the Nickerie River that flowed across the exploration road in tall mesic forest and was surveyed along the exploration road for nine nights from 26 January to 3 February 2006. Area 7 Recon Fly Camp (N 4²7'13" W 56 52'0', 248 m) was adjacent to a larger creek tributary of the Nickerie River that was located in tall mesic forest. It was situated in a valley approximately $2 \mathrm{~km} \mathrm{SW}$ along the road from the new camp and was surveyed for four nights. Transect 11 (N 4 28 ' 1 ' W W $56^{\circ} 51^{\prime} 20$ ”, $386 \mathrm{~m}$ ) was located approximately $2 \mathrm{~km}$ NNE of the new camp in low mesic forest on a plateau and was surveyed for 6 nights. Approximately $500 \mathrm{~m}$ east of Transect 11 was a drill line (N 4²8' ${ }^{\circ}$ 'W 56 51 '13", $\left.311 \mathrm{~m}\right)$, which was surveyed for two nights. (5) Bakhuis Base Camp (N $4^{\circ} 43^{\prime} 49^{\prime}$ "W $56^{\circ} 46^{\prime} 5$ ", $166 \mathrm{~m}$ ) in Area 10 was incidentally sampled for bats while waiting in-transit to other areas during four evenings on 10 January and on 5, 11 and 12 February 2006. The Base Camp is situated in a large clearing in secondary vegetation beside a tributary of the Nickerie River in riverine forest within tall mesic forest. (6) Blanche Marie Vallen, which is an ecotourism facility, was surveyed in the vicinity of Guesthouse Dubois (N 4 45'22" W $56^{\circ} 52^{\prime} 46^{\prime}, 56 \mathrm{~m}$ ) for five days from 6-10 February 2006. It is located in human modified, tall mesic forest on the west bank of the Nickerie River and opposite to Area 13 of the concession.

\section{Survey Methodology}

For unexplored or poorly known regions, the first step of a faunal survey is an assessment of biodiversity. Small nocturnal organisms such as bats, rats, and opossums, however, can only be reliably documented by capturing techniques and even then many are difficult to identify in the hand. Furthermore, some species of mammals cannot be identified without examination of cranial or dental characteristics. Thus, capture and removal methods were used to enable the collection of voucher specimens for species verification and scientific veracity. Individuals prepared as specimens are deposited at the Royal Ontario Museum in Toronto and the National Zoological Collections of Suriname in Paramaribo. However, individuals that were not retained as part of the representative collection were not marked upon release, which may overestimate relative abundance for those particular species that were released and had individuals recaptured.

Field surveys of bats used a maximum of 17 long (12 x $2.6 \mathrm{~m})$ and 20 short $(6 \times 2.6 \mathrm{~m})$ mist nets set and opened on any given night in the forest understorey across trails, creeks, roads, bridges, and clearings. New nets were added on a nightly basis along the transect until the maximum number was set. Nets along the transect trail typically were set in pairs with a short net across the trail and a long net perpendicular to it. The distance between nets was approximately $100 \mathrm{~m}$ with a maximum transect distance of
$1.3 \mathrm{~km}$ along the trail. Nets were set in a variety of microhabitats along the transect including within primary forest, transition areas between primary forest and tree-fall gaps or vine tangles, and in the vicinity of creeks. Nets also were used around the camps and roads in more open areas such as across rivers, along bridges, in clearings, or across roads. In addition, two large $(30 \times 10 \mathrm{~m})$ mist nets were set upwards to $20 \mathrm{~m}$ into the forest canopy in camp clearings and along the exploration roads to target bats flying higher in the canopy. A bat surveying method used only in the wet season is flap trapping [10], which is a recently developed technique for actively catching bats in flight. Bats passing within several meters of the user are scooped with a $2.5 \times 2 \mathrm{~m}$ monofilament net strung between two $4.5 \mathrm{~m}$ telescopic carbon poles. This device effectively catches bat species that are normally under-sampled by conventional methods due to their ability to avoid stationary nets.

Terrestrial and arboreal rats, mice, squirrels, and opossums (non-volant small mammals) were sampled using up to 60 extra large aluminum folding Sherman traps (model XLK) and 120 large aluminum folding Sherman traps (model LFATDG) that were set approximately $5 \mathrm{~m}$ apart and baited with sunflower seeds. New traps were added on a nightly basis along the transect until the maximum number was set. Placement of traps were either on the ground near areas of potential foraging activity such as logs and base of trees, or on vines and low branches situated above the ground. Six single door collapsible Tomahawk traps (model 204) were set on the ground at the base of large trees that had vines going up into the canopy. These traps were used to target larger species of opossums and were baited with sardines.

\section{Data Analyses}

Methodological bias was minimized by standardizing the sampling methods used by two experienced field mammalogists. Seasonal, spatial, and abundance comparisons were based on accumulated nights of effort. To describe and characterize the small mammal baseline data, species diversity is summarized using several measures. Species richness is an unweighted measure of diversity based on the observed number of species. To gauge the rate of species discovery, species accumulation curves are constructed based on the number of nights of effort. Linear regressions were calculated to identify different trends between areas and habitats. Each resultant slope was used in a statistical Ztest for a minimum probability of significant difference $(\mathrm{p}=$ 0.05) from the observed sample mean. Because there are different field methods used for surveying bats and small non-volant mammals, data analyses are separated into these two groups.

Diversity indices are weighted measures that facilitate comparisons between areas or studies. Simpson's index incorporates measures of abundance by proportionality or evenness while taking into account unequal sample sizes. It is defined as $-\ln \sum\left(\left(n^{2}-n\right) /\left(N^{2}-N\right)\right)$, where $n$ is the number of individuals for a species and $\mathrm{N}$ is the total number of individuals for all species [11]. A statistical Z-test was used to identify significantly different $(p=0.05)$ groups from the sample mean. 
Relative species abundance is documented by the number of individuals caught per species in relation to the total catch. Sampling effort for bats are based on the number of nights surveyed and for small non-volant mammals is based on the number of traps set per night. Capture success rate for bats is calculated as the number of individuals caught in nets per night, and for non-volant small mammals is calculated as the percentage of traps that caught individual animals.

Temporal comparisons are based on the 2 field surveys conducted during the dry and wet seasons. Spatial comparisons are done among the general areas and specific habitats sampled. Comparisons of areas are based on the 6 study sites, which encompassed a broader scale and included data from transects and the vicinity around camps. Comparisons of habitats are on a smaller scale specifically between tall mesic forest and low meso-xeric forest types, and were concentrated on transects. There were no camps situated on plateaus because of poor accessibility and logistical constraints, which necessitated the limiting factor for standardizing the amount of effort in habitat comparisons to the lower number of survey nights in the low meso-xeric forest of plateaus.

\section{RESULTS}

\section{Species Richness}

In total, there were 83 species documented during the Bakhuis small mammal study including 68 species of bats (Table 1), 8 species of rats and mice, and 7 species of opossums (Table 2). The dry season sampling recorded 48

Table 1. Species list of 68 bats documented at Bakhuis, Suriname. Species are ranked by total number of captures with number of individuals reported for each of the two study sites during the dry season (Area 22 Recon Fly Camp and SEMC Fly Camp), and four study sites during the wet season (Area 20 Recon Fly Camp, Area 8 Camp, Blanche Marie Vallen, and Bakhuis Base Camp). Numbers of individuals released for each species and site are in parentheses. The dry season, wet season, and combined totals are in bold

\begin{tabular}{|c|c|c|c|c|c|c|c|c|c|}
\hline Species & A22 & SEMC & Dry & $\mathbf{A 2 0}$ & A8 & BMV & BC & Wet & Total \\
\hline Carollia perspicillata & $56(35)$ & $17(7)$ & 73 & $22(4)$ & 13 & $115(104)$ & $2(1)$ & 152 & 225 \\
\hline Artibeus planirostris & $18(2)$ & $6(1)$ & 24 & $26(10)$ & $42(28)$ & & & 68 & 92 \\
\hline Saccopteryx bilineata & 1 & & 1 & $30(9)$ & 16 & $13(6)$ & $12(8)$ & 71 & 72 \\
\hline Saccopteryx leptura & 1 & & 1 & $24(8)$ & $7(1)$ & 5 & $6(1)$ & 42 & 43 \\
\hline Pteronotus personatus & 2 & 2 & 4 & $20(3)$ & 6 & 2 & & 28 & 42 \\
\hline Molossus molossus & & & & & & $39(33)$ & 1 & 40 & 40 \\
\hline Carollia brevicauda & 9 & 4 & 13 & 8 & 7 & $8(2)$ & 1 & 24 & 37 \\
\hline Lonchophylla thomasi & 10 & 4 & 14 & 4 & 3 & 3 & 2 & 12 & 26 \\
\hline Ametrida centurio & 9 & 11 & 20 & & & & 1 & 1 & 21 \\
\hline Eptesicus chiriquinus & & & & 8 & 9 & 1 & 2 & 20 & 20 \\
\hline Rhynchonycteris naso & 5 & 2 & 7 & & & 3 & $7(1)$ & 10 & 17 \\
\hline Molossus rufus & 3 & & 3 & & 12 & & & 12 & 15 \\
\hline Cormura brevirostris & & & & 5 & 3 & $3(1)$ & & 11 & 11 \\
\hline Glossophaga soricina & 1 & 1 & 2 & 2 & & 6 & & 8 & 10 \\
\hline Eptesicus furinalis & 1 & & 1 & & & 7 & 1 & 8 & 9 \\
\hline Lophostoma silvicolum & 1 & 2 & 3 & 3 & & & & 3 & 6 \\
\hline Trachops cirrhosus & 2 & 1 & 3 & 1 & 1 & 1 & & 3 & 6 \\
\hline
\end{tabular}




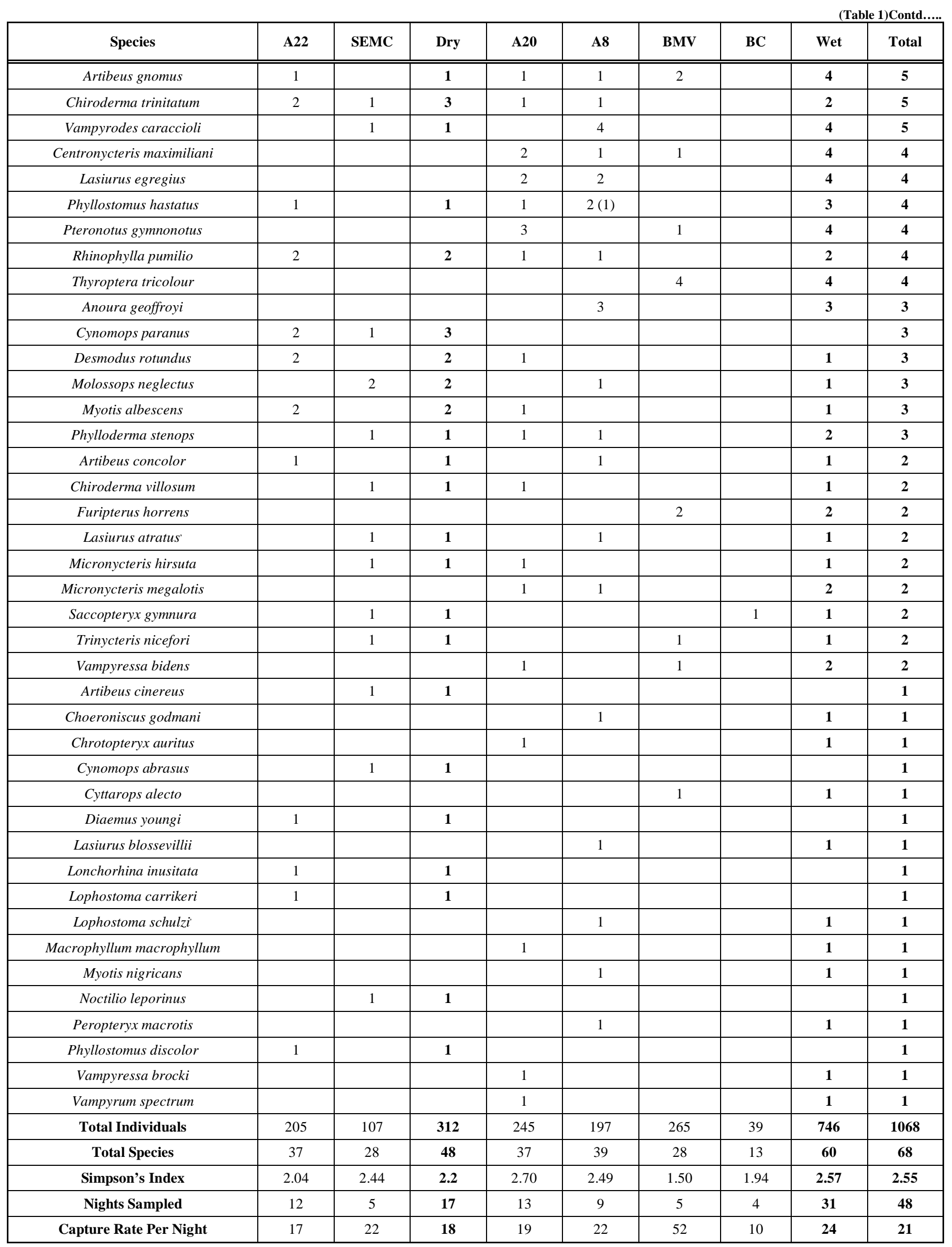


Table 2. Species list of 15 non-volant small mammals (rats, mice, and opossums) documented at Bakhuis, Suriname. Species are ranked by total number of captures with number of individuals reported at the two sampling sites during the dry season (Area 22 Recon Fly Camp and SEMC Fly Camp), and three sampling sites during the wet season season (Area 20 Recon Fly Camp, Area 8 Camp, Blanche Marie Vallen)

\begin{tabular}{|c|c|c|c|c|c|c|c|c|}
\hline Species & A22 & SEMC & Dry & $\mathbf{A 2 0}$ & A8 & BMV & Wet & Total \\
\hline Proechimys guyannensis & 18 & & 18 & 5 & 8 & & 13 & 31 \\
\hline Proechimys cuvieri & 7 & & 7 & 5 & & 4 & 9 & 16 \\
\hline Oryzomys megacephalus & 5 & 1 & 6 & 2 & & 1 & 3 & 9 \\
\hline Neacomys guianae & 3 & & 3 & 3 & & 1 & 4 & 7 \\
\hline Neacomys paracou & 2 & & 2 & 2 & 2 & & 4 & 6 \\
\hline Philander opossum & & & & 1 & & 2 & 3 & 3 \\
\hline Marmosa murina & & & & 1 & & 1 & 2 & 2 \\
\hline Marmosops parvidens & & & & 1 & & & 1 & 1 \\
\hline Marmosops pinheiroi & 1 & & 1 & & & & & 1 \\
\hline Didelphis marsupialis & 1 & & 1 & & & & & 1 \\
\hline Rhipidomys nitela & & & & 1 & & & 1 & 1 \\
\hline Total Individuals & 38 & 2 & 40 & 24 & 12 & 12 & 48 & 88 \\
\hline Total Species & 8 & 2 & 9 & 11 & 4 & 7 & 13 & 15 \\
\hline Simpson's Index & 1.34 & - & 1.42 & 2.36 & 0.82 & 2.11 & 2.09 & 1.75 \\
\hline Nights Sampled & 8 & 4 & 12 & 13 & 9 & 4 & 26 & 38 \\
\hline Trap-Nights & 1400 & 823 & 2223 & 1821 & 1342 & 497 & 3660 & 5883 \\
\hline Capture Rate Per Trap-Nights & $2.7 \%$ & $0.2 \%$ & $1.8 \%$ & $1.3 \%$ & $0.9 \%$ & $2.4 \%$ & $1.3 \%$ & $1.5 \%$ \\
\hline
\end{tabular}

species of small mammals and the wet season recorded 68 species, which was also taxonomically verified by DNA barcoding analysis of genetic sequence divergence [12]. For bats, Area 8 Recon Fly Camp had the highest number of documented species (39), however, it had about $25 \%$ fewer netting nights than the next two most speciose sites (Area 22 and 20). Base Camp had the lowest species diversity (13), the least amount of nights sampled (4), and was the only area without species not found in other areas. There were 18 species of bats that were documented in only one of the

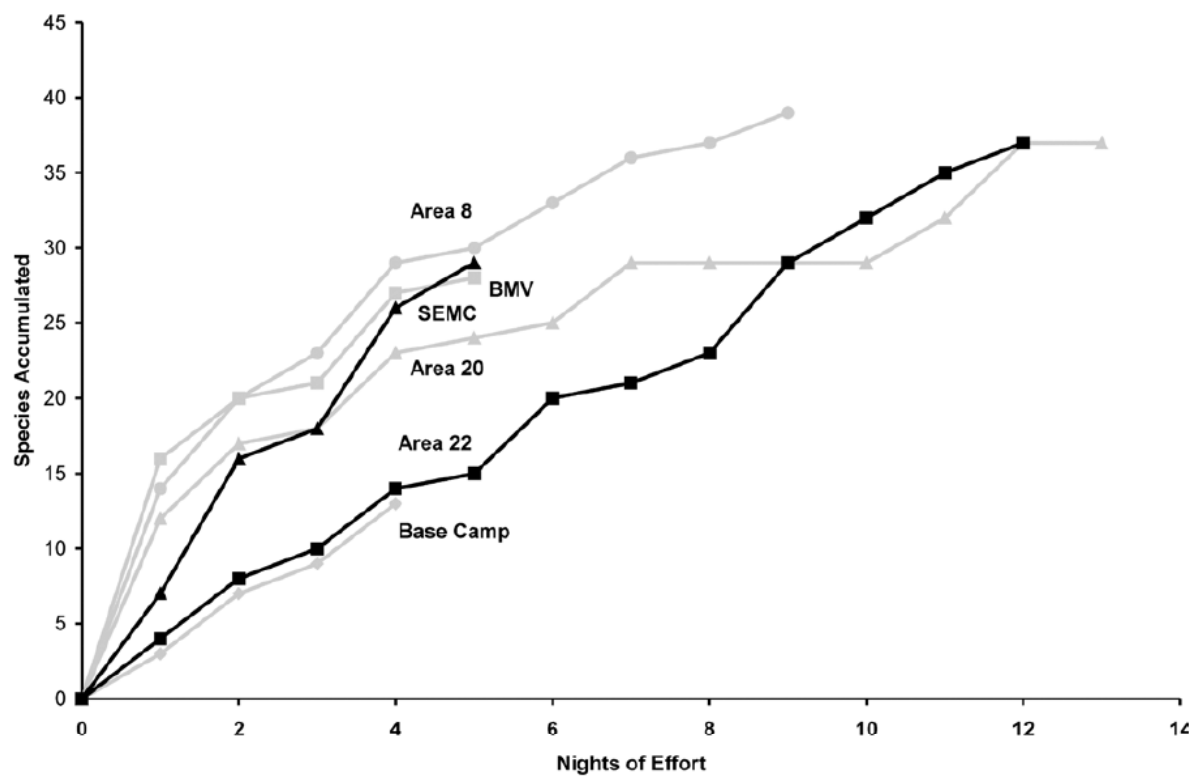

Fig. (2). Species accumulation curves for bats based on nights of effort at the six study sites during the dry (black) and wet (grey) season sampling. 
study sites. In contrast, there were four species (Carollia perspicillata Linnaeus, C. brevicauda Schinz, Artibeus obscurus Schinz, and Lonchophylla thomasi J.A. Allen) that were reported from all six study sites.

Five species of non-volant small mammals (Didelphis imperfecta Mondolfi and Pérez-Hernández, D. marsupialis Linnaeus, Marmosops pinheiroi Pine, Oecomys bicolor Tomes, and Rhipidomys nitela Thomas) were found at only one study site, but no species were caught at all survey sites. The highest number of species documented (11) was at Area 20 Recon Fly Camp. The number of species recorded at SEMC Fly Camp and Area 8 Camp were relatively low, and at Blanche Marie Vallen was relatively high compared to the number of nights sampled.

The accumulated number of bat species recorded at five of the six areas increased on a nightly basis of netting effort. The only exception was during the wet season at Area 20 Recon Fly Camp where the species accumulation was erratic (4 of 13 nights with no additions of new species; Fig. 2).

The overall accumulation of bat species during the wet season was uneven compared with a relatively steady increase during the dry season (Fig. 3). However, the average rates of increase were similar, indicating that potential abiotic factors such as rainfall may influence the activity of bats or the ability to capture them, but only on a random nightly basis. All but 1 of 17 nights of sampling during the dry season added a new species to the accumulated list. In contrast, the species accumulation curve was showing signs of leveling off at the end of the wet season but this was a sampling artifact. The last two nights of effort were at Base Camp where the normal complement of nets was not set, and the previous night at Blanche Marie Vallen added a new species.
The species accumulation curves for non-volant small mammals are more erratic because of lower diversity and abundance compared to bats. However, based on linear regression slopes, Blanche Marie Vallen had a rate that was significantly higher $(\mathrm{p}<0.001)$ than the other sites. Although Area 20 Recon Fly Camp was also surveyed during the wet season, its rate of accumulation was slow but gradually increasing and eventually was the most speciose area (Table 2). However, it also had the highest level of effort. SEMC Fly Camp had a significantly lower ( $p<0.04)$ rate of accumulation than the other sites and was in contrast to the higher species accumulation rate at Area 22 Recon Fly Camp, which was surveyed immediately prior during the dry season.

The overall accumulation of non-volant small mammal species was irregular with over half the number of nights not recording a new addition to the fauna. The accumulation curve reached an asymptote at the end of the wet season with no additional species discovered at Blanche Marie Vallen that were not found at the other earlier sites surveyed.

\section{Species Diversity}

Simpson's index of species diversity for bats was significantly lower $(\mathrm{p}<0.0001)$ at Blanche Marie Vallen in comparison to the other surveyed sites in Bakhuis (Table 1). This difference is attributable to the disproportionately high number of captures of three species (Carollia perspicillata, Molossus molossus Pallas, and Sturnira lilium Davis), which are commonly associated with disturbed habitats.

For non-volant small mammals, Simpson's index was significantly lower $(\mathrm{p}<0.01)$ at Area 8 in comparison to the other sites surveyed (Table 2). Except for a few Sherman traps (20 of 180) set around camp in tall mesic forest, the main trap lines in Area 8 were set in low mesic forest along

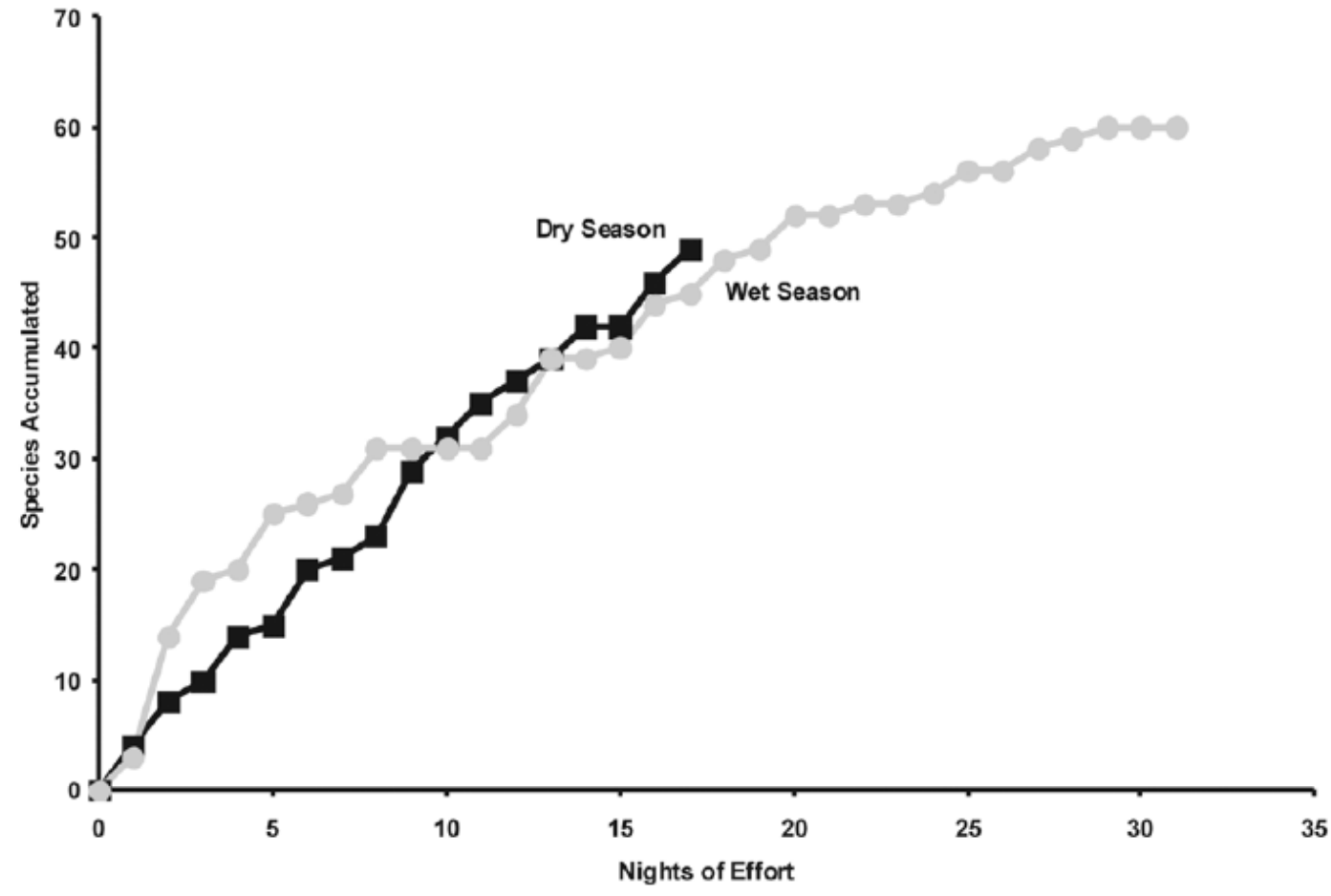

Fig. (3). Seasonal comparison of species accumulation curves for bats. 


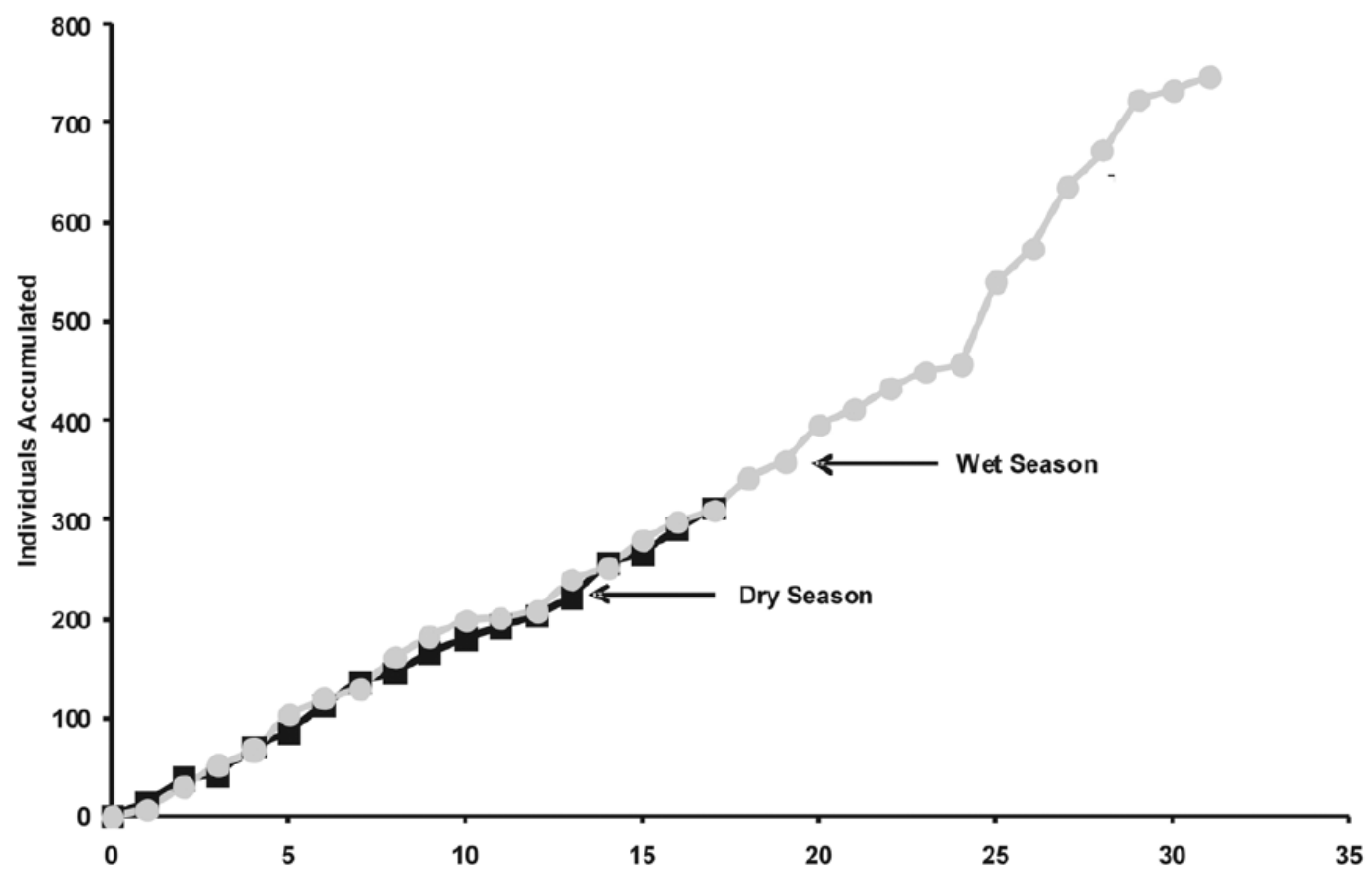

Fig. (4). Seasonal comparison of individuals accumulated for bats.

Transect 11 and a nearby drill line. There was a high number of captures of the Guianan spiny rat (Proechimys guyannensis E. Geoffroy), which was twice the number for the next most abundant species of non-volant small mammal (Table 2).

\section{Relative Abundance}

There were 1,156 captures of small mammals during the survey. The total capture of bats in the wet season was over twice the number in the dry season; however, there were almost twice as many nights of effort in the wet season (Table 1). In contrast, the number of captures of non-volant small mammals was nearly equal between the two seasons although the trapping effort was over $50 \%$ higher in the wet season (Table 2).

The short-tailed fruit bat (Carollia perspicillata) was the commonest bat and was captured at all 6 study sites (Table 1). The accumulation rate of individual bats was almost identical between the seasons with the only noticeable difference being the high number of captures of $C$. perspicillata at Blanche Marie Vallen near the end of the wet season sampling (Fig. 4).

Two species of terrestrial spiny rats (Proechimys guyannensis and $P$. cuvieri Petter) were the most abundant and represented over half of the total captures for non-volant small mammals (Table 2). Both species were found sympatrically in tall mesic forest, but $P$. guyannensis was also found in the drier meso-xeric forest or low mesic forest. In addition, spiny rats were the most common species at all areas except the SEMC Fly Camp, where only one individual each of two other species were caught. The number of accumulated individuals was gradual and relatively even in the wet season as compared to the dry season, which had high trap success for non-volant small mammals at Area 22 Recon Fly Camp but low success at SEMC Fly Camp.

\section{Capture Rates}

The average capture rate of bats during the study was 21 individuals per night and the rate was significantly higher ( $\mathrm{p}$ $<0.001$ ) at Blanche Marie Vallen (Table 1). Likewise, the slope of the accumulation curve for individuals at Blanche Marie Vallen was significantly steeper (Fig. 5). This difference was attributable to over two-thirds of the captures being represented by only 3 species (Carollia perspicillata, Molossus molossus, and Sturnira lilium). The rate of capture was significantly lower ( $\mathrm{p}<0.02)$ at Base Camp, which also is human modified habitat but of more recent disturbance. However, the lower rate at Base Camp is probably due to the deployment of only two mist nets set on two nights and flap trapping done for only a few hours. If the data from these two areas is excluded, the wet season capture rate would decrease to 20 bats per night, which is only slightly higher than the rate of capture (18 bats per night) during the dry season.

The average rate of capture for non-volant small mammals was $1.5 \%$ success per trap (Table 2). In more practical terms, it required 67 traps per night to catch one individual. Between areas, the capture rate was significantly lower $(\mathrm{p}<0.01)$ at the SEMC Fly Camp. Similarly, the accumulation curve for individuals was very shallow for SEMC Fly Camp. In contrast, Area 22 Recon Fly Camp had the highest capture rate but was surveyed immediately prior to SEMC Fly Camp. The individual accumulation rates at Area 22 Recon Fly Camp and Blanche Marie Vallen were significantly higher $(\mathrm{p}<0.03)$ than at the other sites.

\section{Habitat Comparisons}

The accumulation curves of individuals for different habitat types indicated that the lowland tall mesic forest of Transect 13 in Area 20 and Transect 9 in Area 22 had over three times the numbers of bats than the low mesic or meso- 


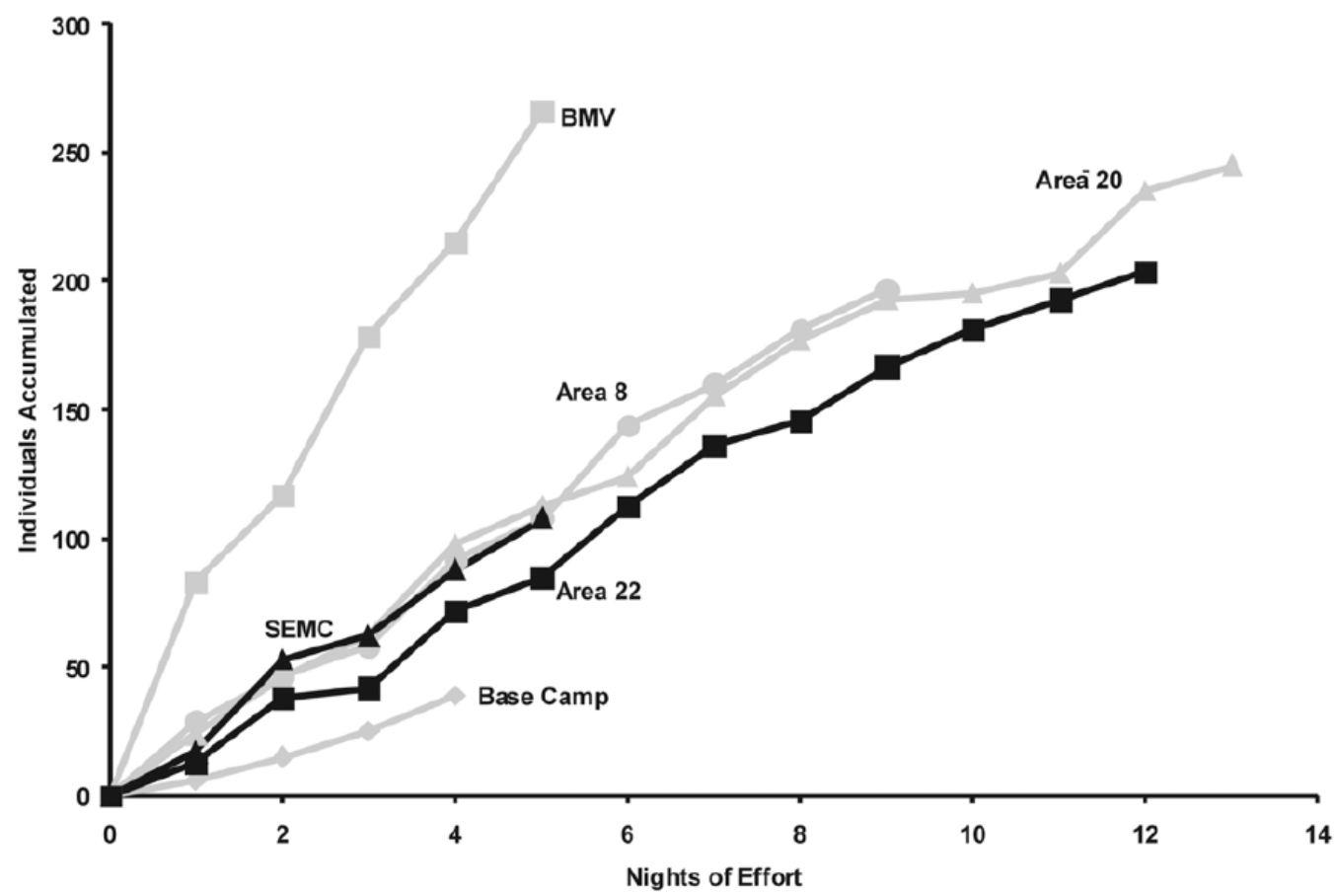

Fig. (5). Individual accumulation curves for bats based on nights surveyed during the dry (black) and wet (grey) season samplings.

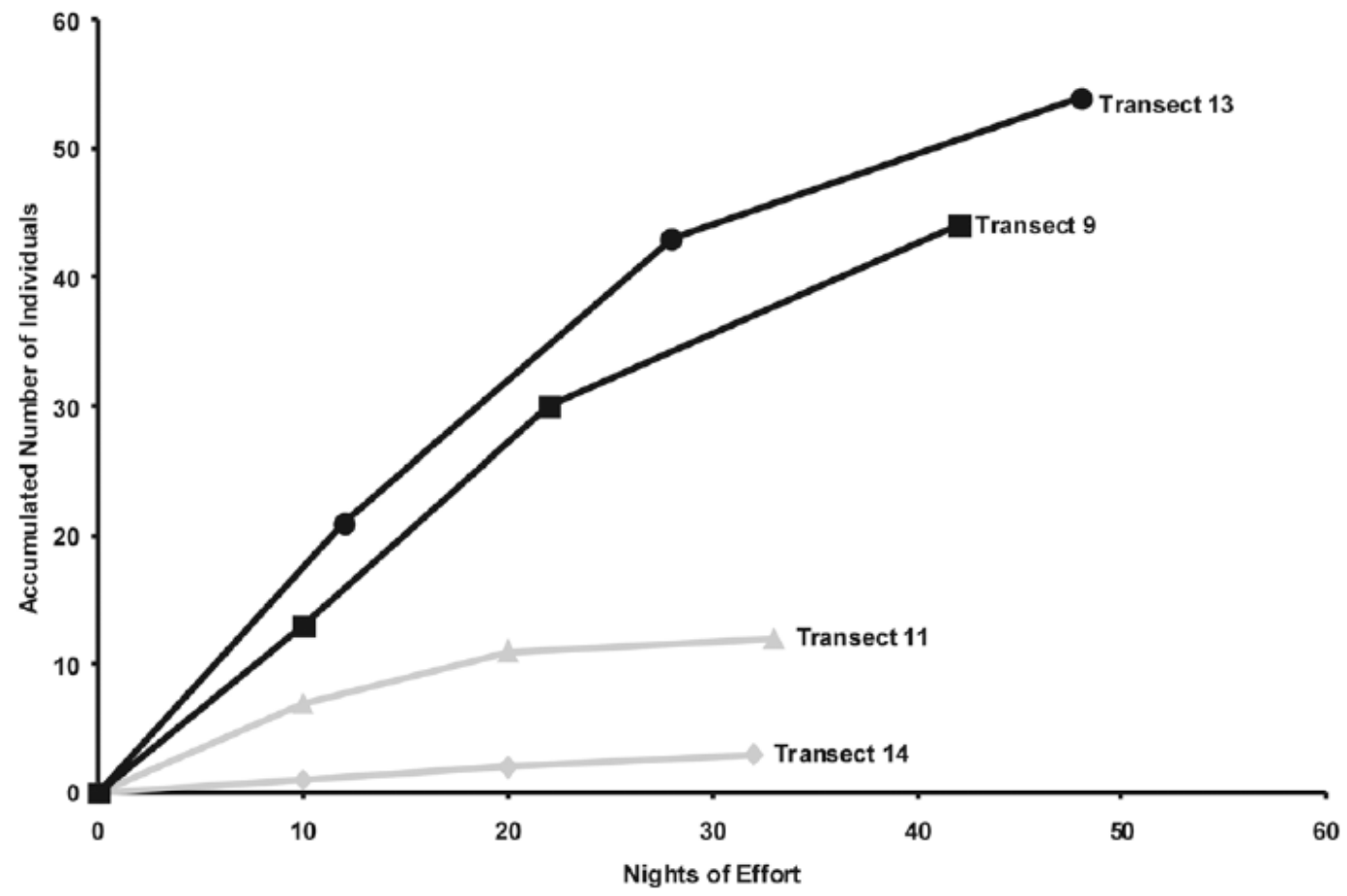

Fig. (6). Accumulation curves for number of individuals of bats mist netted at transects in the surrounding lowland tall mesic forests (black) and in low mesic or meso-xeric forest on plateaus (grey). Each symbol represents the accumulated total over the first three days of surveying on the transects.

xeric forest on plateaus of Transects 11 in Area 8 and Transect 14 in Area 12 (Fig. 6). The accumulation curves of species for different habitat types indicated that lowland tall mesic forest had more species of bats than low mesic or meso-xeric forest on plateaus (Fig. 7). However, Transect 9 in tall mesic forest was only marginally greater than Transects 14 and 11 in low mesic or meso-xeric forest.

The accumulated number of species for non-volant small mammals had no distinction between tall mesic and low mesic or meso-xeric forest but there are differences between 


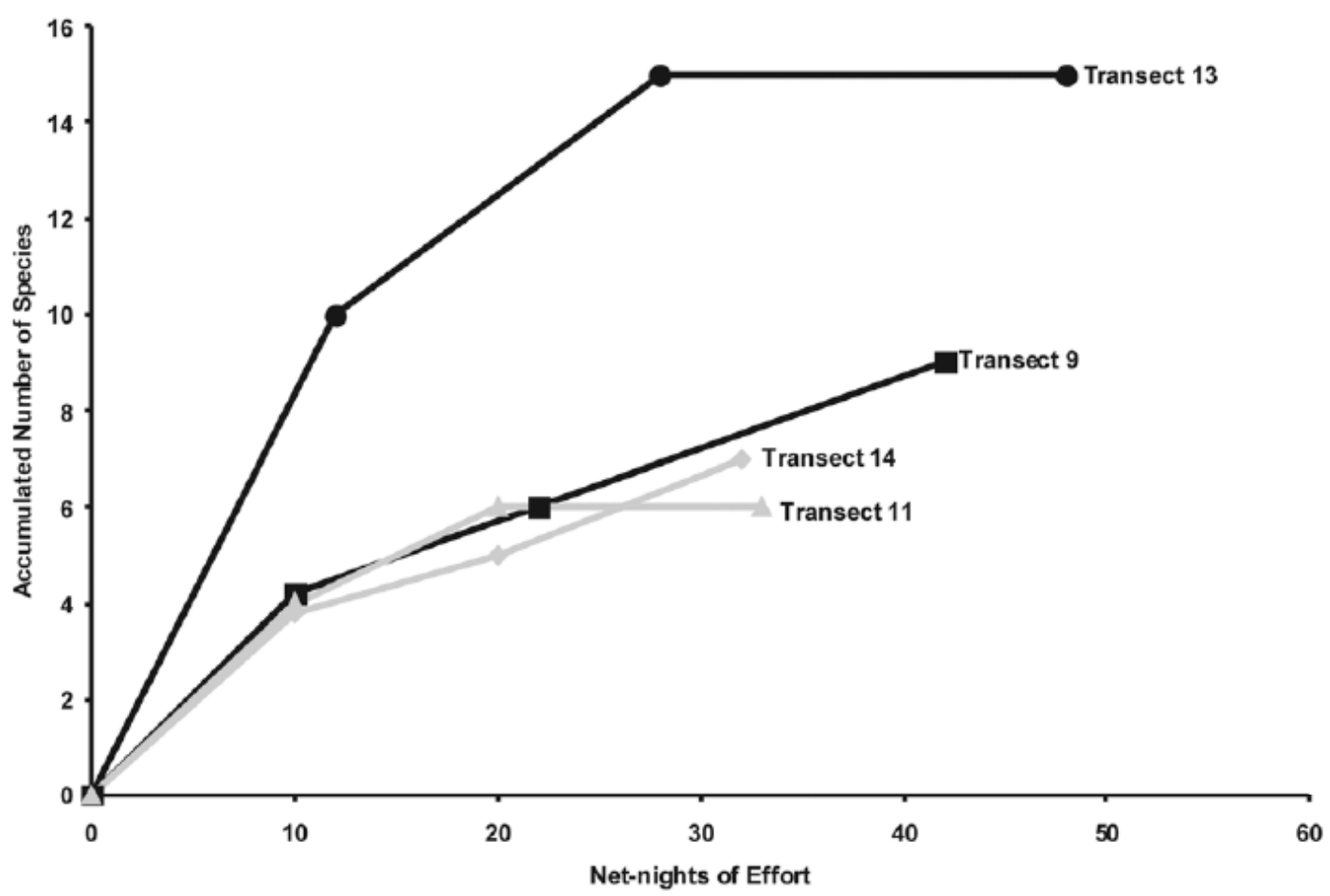

Fig. (7). Accumulation curves for number of species of bats mist netted at transects in the surrounding lowland tall mesic forest (black) andin low mesic or meso-xeric forest on plateaus (grey). Each symbol represents the accumulated total over the first three days of surveying on the transects.

areas that may be related to local population phenomena. For example, there was no success on the first four days of sampling with Sherman traps on Transect 13, however, it eventually documented the highest number of species of any transect. Similarly, for accumulated number of individuals of non-volant small mammals, there were no apparent differences in habitat type between tall mesic and low mesic or meso-xeric forest. The most obvious difference was between Transects 9 and 13 in tall mesic forest, which had extreme values in terms of capture rate.

\section{DISCUSSION}

There are 142 species of small mammals that could potentially be found in the Bakhuis concession area based on general distributional occurrence in lowland forests of Suriname [13]. Although the 83 species documented during the environmental assessment surveys represent only $60 \%$ of the potential diversity, this is an artifact of the relatively short-term duration of the study. Species were still being discovered at the end of the study, reinforcing the notion that not all species are necessarily found in all areas at all times and that more surveys are needed to attain a complete inventory of small mammal diversity. Furthermore, there were four species of bats recorded for the first time in Suriname (Cyttarops alecto Thomas, Saccopteryx gymnura Thomas, Diaemus youngi Jentink, and Lasiurus egregious Peters), indicating the inherent underestimation of biodiversity based on previous studies and distribution maps. Nonetheless, the overall community structure of small mammals at Bakhuis was typical for the Neotropics. There were many species represented by a few individuals but only a few species represented by many individuals (Tables $\mathbf{1}$ and
2). A log normal distribution has also been documented for other studies in La Selva, Costa Rica [14], Barro Colorado Island, Panama [15], Paracou, French Guiana [16], and Iwokrama Forest, Guyana [17]. This indicates that Bakhuis is as equally diverse as these other primary forest sites.

Although there are slight differences in rates of species accumulation and diversity indices, rising accumulation curves also suggest that not all bat species were completely inventoried at the individual study sites and that each site has the potential for equally high numbers of bat species. At the scale of study sites covering approximately $5 \mathrm{~km}$ diameters, which includes lowland and upland areas, there probably are no major differences in terms of overall bat species richness. Possibly because of the relatively high vagility of bats associated with their ability to fly, their species richness is fairly homogeneous across large areas of Bakhuis. The trends in species diversity for non-volant small mammals were less obvious because of the lower numbers of species and individuals recorded. For example, Area 20 had an inauspicious start with no captures in Sherman traps during the first two sampling nights. However, this site eventually documented the highest number of species after 13 nights of surveying indicating a need for longer term studies for nonvolant small mammals as compared to bats.

There were differences, however, between areas in terms of relative abundance of bat species. The disturbed habitat at Blanche Marie Vallen had a low species diversity index because of a large number of captures of Carollia perspicillata, which also contributed to a higher rate of capture compared to the other areas. Furthermore, four species of bats (C. perspicillata, Molossus molossus, Eptesicus furinalis d'Orbigny, and Glossophaga soricina 
Pallas) were roosting in large numbers in the guesthouses and buildings at Blanche Marie Vallen. The latter three species were uncommon or absent at the study sites in Bakhuis. These species are good indicators of human modified and maintained habitats, which may be useful in monitoring post-mining changes to the environment and the success of forest rehabilitation. C. perspicillata was also proposed as a good indicator species of disturbed habitat in Amazonian Peru [18]. An alternative indicator of habitat disturbance is the relative absence of phyllostomine bats [19]. Of the 17 species of phyllostomine bats documented during the environmental assessment in the Bakhuis area, only 3 of these species were recorded at Blanche Marie Vallen, whereas the 5 sites within the concession area each recorded 7-12 of these species. More recent studies have examined the direct effects of logging on bat populations [e.g., 20, 21], which is a more severe form of habitat disturbance than the current construction of exploration roads and associated camp clearings at Bakhuis.

Other indications of differences in community structure between disturbed and undisturbed sites in the Bakhuis region included Sturnira lilium E. Geoffroy being very common along the jeep trails within the forest of Blanche Marie Vallen but which were captured only once within the concession. In addition, two roosts of Thyroptera tricolor Spix were opportunistically found in newly sprouted, unfurled leaves species of Heliconia Linnaeus along the side of the jeep trail and another was flap trapped on the trail. Heliconia and banana (Musa Linnaeus), which are essentially the obligate roosts of disk-winged bats [22], are commonly associated with modified habitats. These plants were prevalent at Blanche Marie Vallen but were not obvious at the other sites, where $T$. tricolor was not caught. These species of Sturnira and Thyroptera also are present in pristine forest, but relative abundance is probably correlated to roost availability and their ease of capture is usually associated with secondary forest.

Although located adjacent to each other in tall mesic forest, the baseline data at Blanche Marie Vallen suggests the presence of substantial disturbance as compared to areas in Bakhuis. Blanche Marie Vallen has been a human modified and maintained habitat for approximately 40 years with large cleared areas, planted palm and fruit trees, permanent wooden buildings, and jeep trails. In contrast, Bakhuis has only recent disturbances within the past two years caused by mining exploration such as the construction of roads and camps that seem to have had a relatively minor effect on community structure of small mammals. This suggests that the forests of Bakhuis can tolerate relatively low levels of disturbance in proportionally small areas over a short duration.

Habitat comparisons for bats indicated a lower species diversity and relative abundance in drier, lower canopy mesic or meso-xeric forest on plateaus, as opposed to the moister, higher canopy mesic forest in the surrounding lowlands. There were no species caught exclusively in upland low mesic or meso-xeric forest that were not also found in the surrounding tall mesic forest, indicating that this habitat represents a reduced subset of small mammal species that were found in surrounding lowland tall mesic forest. Although there were no notable trends for non-volant small mammals, two species of terrestrial spiny rats (Proechimys cuvieri and $P$. guyannensis) were present in tall mesic forest but only $P$. guyannensis was found in low mesic or mesoxeric forest. There were no differences in overall species diversity but there may be habitat preferences among species of non-volant small mammals.

There were no obvious differences between the dry and wet seasons in terms of species diversity of small mammals in spite of rainfall affecting bat activity patterns and methodological bias, such as number of nets set and amount of time nets were opened, on an irregular nightly basis during the wet season. Although there was higher relative abundance of non-volant small mammals during the dry season survey, this was attributable to spatial differences in local population demographics (i.e. high abundance at Area 22), and not to temporal differences related to climatic conditions. However, wet season sampling would directly address this assumption.

\section{CONCLUSIONS}

The community structure of small mammals as summarized by measures of species diversity and relative abundance is useful for characterizing the environment and establishing a baseline reference source, which will be suitable for future monitoring programs. In particular, bats are a good indicator of disturbed secondary habitats that are modified and maintained by humans. The Blanche Marie Vallen site has a significantly lower species diversity index compared to the 5 sites within Bakhuis. The inference is that Blanche Marie Vallen is highly disturbed because the long term maintenance of buildings and clearings have significantly altered the relative abundance of the bat community structure in comparison to the low disturbance from exploration road construction and associated clearings in Bakhuis. The Bakhuis concession area is a highly diverse rainforest ecosystem that can apparently tolerate relatively low levels of disturbance in proportionally small areas over a short duration. The upland xeric forest on plateaus harbor a distinct subset of the species diversity found in the surrounding lowland mesic forest, indicating that not all species of small mammals have broad habitat preferences in this region.

\section{ACKNOWLEDGEMENTS}

I would like to thank Sandra Peters and Alex Borisenko for field assistance. Logistical support was ably provided by Vincent "Reds" Hudson, Bergy, Raoul, Murphy Bronne, and many others from Billiton Maatschappij Suriname (BMS). Kate Steyn, Sue Reuther, and Chris Dalgliesh of SRK Consulting provided funding and invited me to participate in the environmental assessment, and gave constructive criticism on the baseline report that formed the basis of this study.

\section{REFERENCES}

[1] Wilson DE, Cole FR, Nichols JD, Rudran R, Foster MS, Eds. Measuring and Monitoring Biological Diversity: Standard Methods for Mammals. Washington, DC; Smithsonian Institution Press 1996.

[2] Voss RS, Lunde DP, Simmons NB. The mammals of Paracou, French Guiana: a neotropical lowland rainforest fauna, Part 2, nonvolant species. Bull Am Mus Nat Hist 2001; 263: 1-236. 
[3] Husson AM. The mammals of Suriname. Zoölogische Monographieën van het Rijksmuseum van Natuurlijke Historie 1978; $2: 1-569$.

[4] Genoways HH, Williams SL. Records of bats (Mammalia: Chiroptera) from Suriname. Ann Carnegie Mus 1979; 48: 323-35.

[5] Genoways HH, Williams SL, Groen JA. Results of the Alcoa Foundation-Suriname expeditions. V. Noteworthy records of Surinamese mammals. Ann Carnegie Mus 1981; 50: 319-32.

[6] Williams SL, Genoways HH. Results of the Alcoa FoundationSuriname expeditions. II. Additional records of bats (Mammalia: Chiroptera) from Suriname. Ann Carnegie Mus 1980; 49: 213-36.

[7] Williams SL, Genoways HH, Groen JA. Results of the Alcoa Foundation-Suriname expeditions. VII. Records of mammals from central and southern Suriname. Ann Carnegie Mus 1983; 52: 32936.

[8] Lim BK, Engstrom MD, Genoways HH, et al. Results of the Alcoa Foundation-Suriname expeditions. XIV. Mammals of Brownsberg Nature Park, Suriname. Ann Carnegie Mus 2005; 74: 225-74.

[9] Eva HD, Belward AS, de Miranda EE, et al. A land cover map of South America. Global Change Biol 2004; 10: 731-44.

[10] Borissenko AV. A mobile trap for capturing bats in flight. Plecotus et al. 1999; 2:10-19 (in Russian with English summary).

[11] Simpson EH. Measurements of diversity. Nature 1949; 163: 688

[12] Borisenko AV, Lim BK, Ivanova NV, Hanner RH, Hebert PDN. DNA barcoding in surveys of small mammal communities: a field study in Suriname. Mol Ecol Resour 2008; 8: 471-79.

[13] Lim BK, Engstrom MD, Ochoa J. Mammals. In: Hollowell T, Reynolds RP, Eds. Checklist of the terrestrial vertebrates of the Guiana Shield. Bull Biol Soc Washington 2005; 13: 77-92.
[14] Wilson DE. Mammals of La Selva, Costa Rica. In: Gentry AH, Ed. Four Neotropical Rainforests. New Haven; Yale University Press 1990; 273-86.

[15] Handley CO, Wilson DE, Gardner AL, Eds. Demography and natural history of the common fruit bat Artibeus jamaicensis on Barro Colorado Island, Panama. Washington, DC; Smithsonian Institution Press 1991

[16] Simmons NB, Voss RS. The mammals of Paracou, French Guiana: a neotropical lowland rainforest fauna, Part 1, bats. Bull Am Mus Nat Hist 1998; 237: 1-219.

[17] Lim BK, Engstrom MD. Species diversity of bats (Mammalia: Chiroptera) in Iwokrama Forest, Guyana, and the Guianan subregion: implications for conservation. Biodivers Conserv 2001; 10: 613-57.

[18] Wilson DE, Ascorra CF, Solari S. Bats as indicators of habitat disturbance. In: Wilson DE, Sandoval A, Eds. Manu: the Biodiversity of Southeastern Peru. Washington and Lima: Smithsonian Institution and Editorial Horizonte 1996; 613-25.

[19] Fenton MB, Acharya L, Audet D, et al. Phyllostomid bats (Chiroptera: Phyllostomidae) as indicators of habitat disruption in the Neotropics. Biotropica 1991; 24: 440-46.

[20] Ochoa JG. Efectos de la extracción de maderas sobre la diversidad de mamíferso pequeños en bosques de tierras bajas de la Guayana Venezolana. Biotropica 2000; 32: 146-64.

[21] Peters SL, Malcolm JR, Zimmerman BL. Effects of selective logging on bat communities in the southeastern Amazon. Conserv Biol 2006; 20: 1410-21.

[22] Emmons LH, Feer F. Neotropical Rainforest Mammals: A Field Guide. 2nd ed. Chicago; University of Chicago Press 1997.

Received: December 03, 2008

Revised: March 27, 2009

Accepted: April 07, 2009

(C) Burton K. Lim; Licensee Bentham Open.

This is an open access article licensed under the terms of the Creative Commons Attribution Non-Commercial License (http://creativecommons.org/licenses/bync/3.0/), which permits unrestricted, non-commercial use, distribution and reproduction in any medium, provided the work is properly cited. 